\title{
Geobacter pickeringii sp. nov., Geobacter argillaceus sp. nov. and Pelosinus fermentans gen. nov., sp. nov., isolated from subsurface kaolin lenses
}

Correspondence

Evgenya S. Shelobolina

shelobolina@wisc.edu

\section{INTRODUCTION}

Kaolin is a rock consisting predominantly of the clay mineral kaolinite, which is important for the production of

tPresent address: Department of Geology and Geophysics, University of Wisconsin-Madison, 1215 W Dayton St. A362, Madison, WI 53706, USA.

Abbreviations: AQDS, anthraquinone-2,6, disulfonate; NTA, nitriloacetic acid; OM, outer membrane; PCFO, poorly crystalline ferric oxide.

The GenBank/EMBL/DDBJ accession numbers for the 16S rRNA gene sequences of Geobacter pickeringii $\mathrm{G}_{13}{ }^{\top}$, Geobacter argillaceus $\mathrm{G} 12^{\top}$ and Pelosinus fermentans $\mathrm{R}^{\top}$ are DQ145535, DQ145534 and D0145536, respectively. paper as well as porcelain and ceramics. It is mined worldwide from subsurface kaolin lenses and has varying degrees of purity and whiteness. Kaolinite is a product of the weathering of aluminium silicate minerals, with feldspar being the most common source mineral. When conditions are favourable for weathering, white kaolin without discolouring impurities, such as iron oxides (goethite, hematite), sulfide (pyrite) and organic matter, is formed (Hurst \& Pickering, 1997; Elzea Kogel et al., 2002). Depending on their origin, kaolins and kaolin-containing source rocks are either mildly acidic ( $\mathrm{pH} 5-5.5)$ (Elzea Kogel et al., 2002) or slightly alkaline (pH 7-8.5) (Solodkii, 1995). 
Subsurface kaolin lenses are not optimal environments for microbial growth due to the fine mineral particle size of clay and consequently the low hydraulic conductivity. However, cultivation-dependent most probable number analysis (Shelobolina et al., 1999, 2005) and cultivation-independent lipid biomarker analysis (Osipov \& Turova, 1997) have shown the presence of a variety of physiological groups of micro-organisms in kaolin samples of differing ages and origins collected from distant geographical locations in Russia, Ukraine and the USA. Stimulation of indigenous iron-reducing bacteria in kaolin results in a decrease of the $\mathrm{Fe}(\mathrm{III}):[\mathrm{Fe}(\mathrm{II})+\mathrm{Fe}(\mathrm{III})]$ ratio (Shelobolina et al., 1999, 2005), iron solubilization (Turova et al., 1996; Lee et al., 1999; Shelobolina et al., 1999) and in a dramatic increase in the efficacy of iron extraction by magnetic separation (Turova et al., 1996; Vodyanitskii et al., 1997; Shelobolina et al., 1999). The ability of indigenous bacteria to influence iron mineralogy in kaolin suggests that bacteria have played a significant role in the natural removal of iron impurities from kaolin at the subsurface (Hurst \& Pickering, 1997; Elzea Kogel et al., 2002; Shelobolina et al., 2005) and can be used for the development of microbially mediated industrial-scale iron removal from tinted kaolin (Avakyan et al., 1997; Lee et al., 1999). The goal of this project was to isolate representative $\mathrm{Fe}(\mathrm{III})$-reducing bacteria from kaolin clays that might be involved in these processes. Three novel anaerobic Gram-negative micro-organisms were isolated from subsurface kaolin lenses in Russia and the USA. Two strains conserved energy from the oxidation of the organic matter with the reduction of $\mathrm{Fe}(\mathrm{III})$, whereas the third organism was capable of reducing $\mathrm{Fe}(\mathrm{III})$ only in the presence of a fermentable substrate.

\section{METHODS}

Study sites and sample collection. Strains $\mathrm{G} 12^{\mathrm{T}}$ and $\mathrm{G} 13^{\mathrm{T}}$ were isolated from subsurface kaolin lenses in Georgia (USA). Strain $\mathrm{G}_{12}^{\mathrm{T}}$ was isolated from tan kaolin of the Late Paleocene age from the Thiele Kaolin Co. Avant mine, $1 \mathrm{~km}$ west of GA highway 272, GA. Strain $\mathrm{G}^{\mathrm{T}}{ }^{\mathrm{T}}$ was isolated from kaolin from the Huber Formation of the Eocene age taken from the Thiele General Refractories clay mine, $3.2 \mathrm{~km}$ south of Tabernacle Church, GA. Both samples were collected in November 1999. Large pieces of kaolin were taken from freshly exposed surfaces in active mines using a mine excavator and/or a geological pickaxe. Samples were then wrapped with plastic and sent by an overnight delivery service to the laboratory. After arrival at the laboratory, all samples were placed into an $\mathrm{N}_{2}$-filled glove bag. Large pieces of kaolin samples were broken with sterile knives. The middle portion of the samples was extracted, homogenized and dispensed into serum bottles $(160 \mathrm{ml})$ for immediate experimentation or into large $(2000 \mathrm{ml})$ sterilized Pyrex bottles with thick rubber stoppers for storage and/or later use.

Strain $R 7^{\mathrm{T}}$ was isolated from primary kaolin of the Zhuravlinii Log eluvial deposit (located near the town of Plast, Chelabinsk region, Russia). Kaolin was collected in August 1995 using a mine excavator. The sample was placed in a large paper bag and shipped by regular mail to the State University of Management, Russia, to test its suitability for ceramics production. Immediately after arrival at the State University of Management, an aliquot of this kaolin was taken and placed into a large $(1000 \mathrm{ml})$ sterilized bottle with a thick rubber stopper. The bottle headspace was gassed with $\mathrm{N}_{2}$. Microbial enrichments were established at the Institute of Microbiology of the Russian Academy of Sciences as part of a study into the role of micro-organisms within kaolins in the processes of iron solubilization and transformation (Shelobolina et al., 1999).

Media and cultivation. Strict anaerobic techniques (Miller \& Wolin, 1974; Balch et al., 1979) were used throughout. An anaerobic basal bicarbonate-buffered freshwater (FW) medium (Lovley \& Phillips, 1988) was dispensed into $27 \mathrm{ml}$ anaerobic pressure tubes (Bellco Glass) or $160 \mathrm{ml}$ serum bottles under $\mathrm{N}_{2} / \mathrm{CO}_{2}(80: 20)$. The tubes or bottles were capped with butyl rubber stoppers and sterilized by autoclaving. The reducing agents were $\mathrm{FeCl}_{2}(1.3 \mathrm{mM})$ for $\mathrm{Fe}$ (III)-containing media and cysteine $(0.5 \mathrm{mM})$ for all other media and these were added after the medium was autoclaved.

Enrichment cultures with Georgia kaolin (USA) were initiated in $160 \mathrm{ml}$ serum bottles containing $90 \mathrm{ml}$ freshwater medium and $10 \mathrm{~g}$ clay from the site. Poorly crystalline ferric oxide (PCFO) $\left(100 \mathrm{mmol} \mathrm{l}^{-1}\right)$ was prepared as described previously (Lovley \& Phillips, 1986a) and used as the terminal electron acceptor for enrichment and isolation of the strains. Enrichments were established with hydrogen, acetate $(10 \mathrm{mM})$, lactate $(10 \mathrm{mM})$ or intrinsic organic matter (no electron donor added) as the electron donors. Strain $\mathrm{G} 12^{\mathrm{T}}$ was recovered from an enrichment culture established with intrinsic organic matter as the electron donor. The sample of tan kaolin from the Thiele Kaolin Co. Avant mine had 5.3\% (w/w) of organic carbon. Acetate $(10 \mathrm{mM})$ was the electron donor for the isolation of strain $\mathrm{G} 12^{\mathrm{T}}$. Strain $\mathrm{G} 13^{\mathrm{T}}$ was isolated from an enrichment culture established with lactate $(10 \mathrm{mM})$ as the electron donor. Isolates were recovered with a roll-tube method (Hungate, 1969). BBL agar (Becton Dickinson; $1.5 \%$ ) was used as the solidifying agent. An inoculum $(0.7 \mathrm{ml})$ from the 10 -fold serial dilutions of the enrichment culture in a liquid FW medium was added to $27 \mathrm{ml}$ pressure tubes containing $7 \mathrm{ml}$ melted medium. The contents were mixed gently and the pressure tubes were rolled with a tube spinner (Bellco Glass). The roll-tubes were incubated vertically at $30^{\circ} \mathrm{C}$. Individual colonies were transferred to the pressure tubes with $2 \mathrm{ml}$ liquid FW medium containing PCFO as the electron acceptor and either acetate (for strain $\mathrm{G}_{12}{ }^{\mathrm{T}}$ ) or lactate (for strain $\mathrm{G} 13^{\mathrm{T}}$ ) as the electron donors.

The enrichment culture with Russian kaolin was initiated in 1995 and supported for 4 years in $27 \mathrm{ml}$ pressure tubes containing $9 \mathrm{ml} \mathrm{FW}$ medium supplemented with $20 \mathrm{mM}$ lactate and $100 \mathrm{mmol}^{-1}$ PCFO. In 1999, the original enrichment culture was transferred to FW medium containing hydrogen as the electron donor, acetate as the carbon source and $100 \mathrm{mmol} \mathrm{l}^{-1} \mathrm{PCFO}$ as the electron acceptor. Strain $\mathrm{R} 7^{\mathrm{T}}$ was isolated from the resulting enrichment culture, which was transferred onto anaerobic agar plates solidified with $1.2 \%$ purified agar (BBL agar; Becton Dickinson) containing lactate $(20 \mathrm{mM})$ as the electron donor and $\mathrm{Fe}(\mathrm{III})$-pyrophosphate $(10 \mathrm{mM})$ as the electron acceptor. Agar plates were incubated in an anaerobic chamber under an atmosphere of $\mathrm{N}_{2} / \mathrm{CO}_{2} / \mathrm{H}_{2}(83: 10: 7)$ at $30^{\circ} \mathrm{C}$. For further study, individual colonies were transferred to liquid medium containing hydrogen as the electron donor, acetate as the carbon source and $\mathrm{Fe}(\mathrm{III})$-pyrophosphate as the electron acceptor. Following isolation, strain $\mathrm{R}^{\mathrm{T}}$ was maintained on FW medium supplemented with $20 \mathrm{mM}$ glucose.

Screening of potential electron donors and acceptors. The criterion used to determine whether isolates could utilize a particular electron donor or acceptor was the ability of the isolates to grow in presence of a potential donor or acceptor for 3-5 successive $10 \%$ transfers.

For strains $\mathrm{G} 12^{\mathrm{T}}$ and $\mathrm{G} 13^{\mathrm{T}}$, the electron donor used to evaluate potential electron acceptors was acetate. Hydrogen was used for strain 
$\mathrm{R} 7^{\mathrm{T}}$ with $5 \mathrm{mM}$ acetate added as the carbon source. The following electron acceptors were tested: oxygen ( $5 \%$ of the headspace of the culture), PCFO (100 mmol $\left.\mathrm{l}^{-1}\right), \mathrm{Fe}(\mathrm{III})$ citrate $(45 \mathrm{mM}), \mathrm{Fe}(\mathrm{III})$ nitriloacetic acid (NTA) $(10 \mathrm{mM}), \mathrm{Fe}(\mathrm{III})$ pyrophosphate $(10 \mathrm{mM})$, $\mathrm{MnO}_{2}\left(30 \mathrm{mmol} \mathrm{l}{ }^{-1}\right)$, nitrate $(10 \mathrm{mM})$, nitrite $(10 \mathrm{mM})$, thiosulfate $(10 \mathrm{mM})$, sulfite $(10 \mathrm{mM})$, sulfate $(10 \mathrm{mM})$, fumarate $(40 \mathrm{mM})$, anthraquinone-2,6, disulfonate (AQDS, $5 \mathrm{mM}), S^{0}\left(1 \mathrm{~g} \mathrm{l}^{-1}\right)$ and structural $\mathrm{Fe}(\mathrm{III})\left(6 \mathrm{mmol}^{-1}\right)$. Model ferruginous smectite (nontronite) SWa-1 from Grant County, WA, USA (Source Clays Repository, Clay Minerals Society) was used as a source of structural Fe(III). SWa-1 has a cation composition of $\mathrm{Na}_{0.87}\left(\mathrm{Si}_{7.29} \mathrm{Al}_{0.62}\right)\left(\mathrm{Fe}_{2.67}^{3+} \mathrm{Fe}_{0.01}^{2+} \mathrm{Al}_{1.08} \mathrm{Mg}_{0.23}\right)$ (Manceau et al., 2000). The clay suspension was prepared as described earlier (Shelobolina et al., 2003). Fe(III) and Mn(IV) reduction were monitored as the accumulation of $\mathrm{Fe}(\mathrm{II})$ or $\mathrm{Mn}(\mathrm{II})$. AQDS reduction was monitored as a colour change in the medium from an opaque pink to a bright orange. Reduction of elemental sulfur was determined by adding elemental sulfur $\left(\mathrm{g} \mathrm{l}^{-1}\right)$ to the medium and monitoring sulfide production by the methylene blue method (Cline, 1969). Growth on the other electron acceptors was monitored by measuring turbidity at $600 \mathrm{~nm}$. Controls contained no electron acceptor.

The ability of washed cell suspensions to reduce U(VI) was determined as previously described (Shelobolina et al., 2004) using uranyl acetate $(1 \mathrm{mM})$ as the electron acceptor, acetate $(5 \mathrm{mM})$ as the electron donor and the following reaction buffer $\left(1^{-1}\right): 2.5 \mathrm{~g} \mathrm{NaHCO}_{3}, 0.25 \mathrm{~g} \mathrm{NH}_{4} \mathrm{Cl}$, $0.006 \mathrm{~g} \mathrm{NaH}_{2} \mathrm{PO}_{4} \cdot \mathrm{H}_{2} \mathrm{O}, 0.1 \mathrm{~g} \mathrm{KCl}$. Cells were added to the reaction buffer to give a final protein concentration of $0.01 \mathrm{mg} \mathrm{ml}^{-1}$.

Experiments to screen potential electron donors were performed in freshwater medium bubbled with $\mathrm{N}_{2} / \mathrm{CO}_{2}(80: 20)$ and supplemented with either $100 \mathrm{mmol}^{-1}$ PCFO (for strains $\mathrm{G}^{2} 2^{\mathrm{T}}$ and $\mathrm{G}^{\mathrm{T}} 3^{\mathrm{T}}$ ) or $10 \mathrm{mM} \mathrm{Fe}$ (III) NTA (for strain R7 ${ }^{\mathrm{T}}$ ) as the electron acceptors. In order to decrease the amount of carry-over substrate, electron donor (acetate)-limited culture was used for the first transfer of strains $\mathrm{G} 12^{\mathrm{T}}$ and $\mathrm{G} 13^{\mathrm{T}}$. Alternative electron donors were added to the medium from sterile anoxic stock solutions to give a final concentration of 10-20 mM, except for amino acids that were tested at a final concentration $0.1 \mathrm{~g} \mathrm{l}^{-1}$. Controls included no donor and donor alone (for potentially fermentable substrates).

Analytical techniques. Chelated and poorly crystalline forms of iron were quantified by the ferrozine assay (Lovley \& Phillips, 1986b; Phillips \& Lovley, 1987). Structural Fe(II) and Fe(III) in the clay were determined by hydrofluoric acid extraction followed by the 1,10-phenanthroline assay as described by Stucki (Stucki, 1981) and modified by Komadel and Stucki (Komadel \& Stucki, 1988). $\mathrm{Mn}(\mathrm{II})$ concentrations were monitored as described previously (Kashefi \& Lovley, 2000). Cells were counted with acridine orange staining and epifluorescence microscopy as described previously (Hobbie et al., 1977).

$16 S$ rRNA gene sequencing and phylogenetic analysis. DNA was extracted from strains $\mathrm{G} 12^{\mathrm{T}}, \mathrm{G} 13^{\mathrm{T}}$ and $\mathrm{R} 7^{\mathrm{T}}$ using the FastDNA SPIN kit (Bio101). The 16S rRNA gene was amplified using the bacterial forward primer $8 \mathrm{~F}$ (AGAGTTTGATCMTGGCTCAG) and the universal reverse primer 1525R (AAGGAGGTFWTCCARCC). These primers and the conserved internal primers $338 \mathrm{~F}$ (ACTCCTACGGGAGGCAGC), 519F (CAGCACGCCGCGGTAATFWC), 519R (GWATTACCGCGGCKGCTG), 907R (CCGTCAATTCMTTTRAGTTT) and 1392R (ACGGGCGGTGTGTRC) were used to obtain the nearly complete sequence. PCR mixtures contained: a $1 \times$ concentration of $\mathrm{Q}$ and Taq polymerase buffers (Qiagen), $0.5 \mu \mathrm{g}$ bovine serum albumin, $200 \mu \mathrm{M}$ deoxyribonucleoside triphosphates (Sigma-Aldrich), $25 \mathrm{pmol}$ forward and reverse primers (Sigma) and 1.25 U Taq polymerase (Qiagen). PCR tubes containing all the reaction components except the template and Taq polymerase were UV irradiated for $7 \mathrm{~min}$ to ensure sterility. Reactions were performed in a Peltier thermal cycler (PTC 200) beginning with a 5 min denaturation at $95^{\circ} \mathrm{C}$ and then $25-30$ cycles of $94{ }^{\circ} \mathrm{C}(30 \mathrm{~s}), 45^{\circ} \mathrm{C}(1 \mathrm{~min}), 72{ }^{\circ} \mathrm{C}$ ( $1 \mathrm{~min}$ ) and a final $10 \mathrm{~min}$ elongation at $72^{\circ} \mathrm{C}$. The $16 \mathrm{~S}$ rRNA gene fragments from strains $\mathrm{G} 12^{\mathrm{T}}$ and $\mathrm{G} 13^{\mathrm{T}}$ and $\mathrm{R} 7^{\mathrm{T}}$ were compared with the GenBank nucleotide and protein databases using the BLASTN and BLASTX algorithms (Altschul et al., 1990). Representative sequences from the Sporomusa-Pectinatus-Selenomonas group, members of the genus Geobacter and other genera were obtained from GenBank for phylogenetic analysis. Nucleotide sequences were manually aligned in the Genetic Computer Group (GCG) sequence editor (Wisconsin Package version 10). Aligned sequences were imported into PAUP 4.0b 4a (Swofford, 1998) where phylogenetic trees were inferred. Identical branching orders were observed with maximum-parsimony and distance-based algorithms when $16 \mathrm{~S}$ rRNA gene sequences were compared. Bootstrap values were calculated by distance analysis.

Determination of the $\mathbf{G}+\mathbf{C}$ content of DNA. The Deutsche Sammlung von Mikroorganismen und Zellkulturen identification service performed the DNA $\mathrm{G}+\mathrm{C}$ content analysis for strain $\mathrm{R}^{\mathrm{T}}$ (Cashion et al., 1977). The DNA G $+\mathrm{C}$ content of strains $\mathrm{G} 12^{\mathrm{T}}$ and $\mathrm{G} 3^{\mathrm{T}}$ was determined using a fluorometric technique employing real-time PCR (Gonzalez \& Saiz-Jimenez, 2002, 2004). Genomic DNA standards from Clostridium acetobutylicum (ATCC 824D; $30 \mathrm{~mol} \% \mathrm{G}+\mathrm{C}$ ), Escherichia coli K-12 (ATCC 700926; $50 \mathrm{~mol} \%$ $\mathrm{G}+\mathrm{C}$ ), Pseudomonas aeruginosa PAO1 (ATCC 47085D; $66 \mathrm{~mol} \%$ $\mathrm{G}+\mathrm{C}$ ) and Halobacterium sp. (ATCC 700922D; $67 \mathrm{~mol} \% \mathrm{G}+\mathrm{C}$ ) were obtained from the ATCC. Thermal denaturation was performed with approximately $2.5 \mu \mathrm{g}$ DNA from each novel isolate. Thermal conditions consisted of a ramp from $55^{\circ} \mathrm{C}$ to $90{ }^{\circ} \mathrm{C}$ at $0.5^{\circ} \mathrm{C} \min ^{-1}$ on a Bio-Rad iCycler. Fluorescent melt curves for both sample and standard DNA were generated in triplicate. The DNA $\mathrm{G}+\mathrm{C}$ content for strains $\mathrm{G} 12^{\mathrm{T}}$ and $\mathrm{G} 13^{\mathrm{T}}$ was calculated using linear regression analyses of melting temperatures $\left(T_{\mathrm{m}}\right)$ against the $\mathrm{G}+\mathrm{C}$ content of the standard DNA.

\section{RESULTS AND DISCUSSION}

\section{Characteristics of strains $\mathbf{G}^{1}{ }^{\boldsymbol{T}}$ and $\mathbf{G} 13^{\mathbf{T}}$}

Cells of strains $\mathrm{G} 12^{\mathrm{T}}$ and $\mathrm{G} 13^{\mathrm{T}}$ were Gram-negative, motile, regular rods, $1-2 \mu \mathrm{m}$ long and $0.6 \mu \mathrm{m}$ in diameter. On anaerobic solidified FW medium, colonies were $1-2 \mathrm{~mm}$ in diameter. Colonies were pink on fumarate $(20 \mathrm{mM}$, strain $\mathrm{G} 13^{\mathrm{T}}$ ) due to the high $c$-type cytochrome content of cells of species of the genus Geobacter (Lovley et al., 2004) and black on PCFO $\left(100 \mathrm{mM}\right.$, strains $\mathrm{G} 12^{\mathrm{T}}$ and $\left.\mathrm{G} 13^{\mathrm{T}}\right)$ due to formation of dark coloured $\mathrm{Fe}(\mathrm{II})$-bearing minerals such as magnetite (Lovley et al., 1987). When grown with Fe(III) as the electron acceptor, cells had one lateral flagellum (Fig. 1a, b).

Cells of strain $\mathrm{G} 13^{\mathrm{T}}$ exhibited multiple short and elongated tubular projections (blebs) on the cell surface (Fig. 1b). Although blebbing of outer membrane (OM) followed by the formation of membrane vesicles has been described for a number of other Gram-negative bacteria (Beveridge, 1999; Kuehn \& Kesty, 2005), this is the first Geobacter species for which formation of large quantities of blebs has been demonstrated. There are several hypotheses for the formation of blebs. Blebbing of the OM could be result of an overproduction of OM, compared with peptidoglycan (Wensink \& Witholt, 1981) or the result of cell wall turnover during growth (Zhou et al., 1998). Blebbing of the 

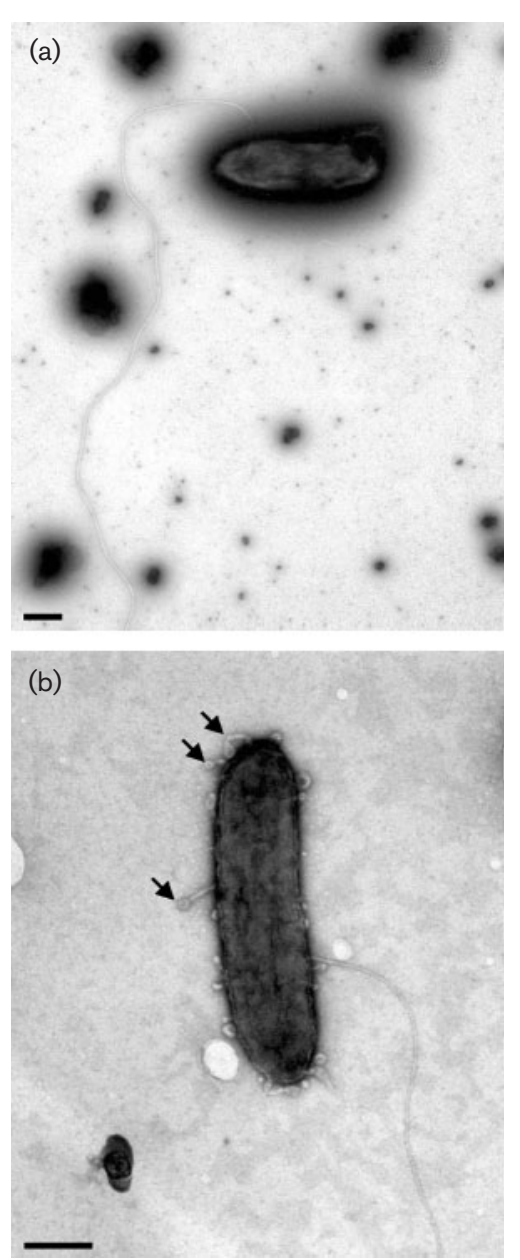

Fig. 1. Morphology of negatively stained cells of strains $\mathrm{G} 12^{\top}$ (a) and $\mathrm{G}_{13}{ }^{\top}$ (b). Both strains were grown on acetate as the electron donor and PCFO as the electron acceptor. Cells were harvested in the middle exponential phase. Cells of strain $\mathrm{G}_{13}{ }^{\top}$ exhibit short and elongated tubular projections (blebs) on the cell surface (b, shown with arrows). Bars, $0.5 \mu \mathrm{m}$.

$\mathrm{OM}$ increases the surface area of the cells, which might improve nutrient uptake. Formation of blebs in an Fe(III)reducing bacterium, Acidophilium cryptum JF-5, has been hypothesized to enhance cellular contact with non-soluble $\mathrm{Fe}(\mathrm{III})$ hydroxides that are utilized as electron acceptors (Küsel et al., 1999). In addition, when OM vesicles form as the result of OM blebbing, they entrap some of the underlying periplasm which enables the bacteria to secrete proteins, lipids and DNA into the extracellular medium (Forsberg et al., 1981; Dorward et al., 1989; Dorward \& Garon, 1990; Kadurugamuwa \& Beveridge, 1996; Kadurugamuwa et al., 1998; Li et al., 1998; Ciofu et al., 2000; Kobayashi et al., 2000; Yaron et al., 2000). Vesicles can also mediate the coaggregation of bacteria, enabling biofilm formation and colonization (Grenier \& Mayrand, 1987; Whitchurch et al., 2002). Therefore, the formation of blebs may give strain $\mathrm{G}_{1} 3^{\mathrm{T}}$ a growth advantage over other micro-organisms.
With acetate $(20 \mathrm{mM})$ as the electron donor and ferric citrate $(50 \mathrm{mM})$ as the electron acceptor, growth of strains $\mathrm{G} 12^{\mathrm{T}}$ and $\mathrm{G} 13^{\mathrm{T}}$ was most rapid at $30^{\circ} \mathrm{C}$ and there was no growth at temperatures below $10{ }^{\circ} \mathrm{C}$. The upper growth temperature was $36^{\circ} \mathrm{C}$. Optimal $\mathrm{pH}$ for growth was 6.2-6.8 for strain $\mathrm{G} 12^{\mathrm{T}}$ and $\mathrm{pH}$ 6.6-7.2 for strain $\mathrm{G} 13^{\mathrm{T}}$. No growth was observed at $\mathrm{pH}$ values lower than 5.8 for either isolate. The upper $\mathrm{pH}$ value for growth was 7.4 for strain $\mathrm{G} 12^{\mathrm{T}}$ and 8.0 for strain $\mathrm{G} 13^{\mathrm{T}}$.

With acetate $(20 \mathrm{mM})$ serving as the electron donor, both strains were capable of reducing the following electron acceptors: $60-100 \mathrm{mmol} \mathrm{PCFO}^{-1}$, ferric citrate $(50 \mathrm{mM})$, $\mathrm{Fe}$ (III) NTA (10 mM), Fe(III) pyrophosphate $(10 \mathrm{mM})$, $30 \mathrm{mmol} \mathrm{MnOOH} \mathrm{l}^{-1}$ and $1 \mathrm{~g}$ elemental sulfur $\mathrm{l}^{-1}$ (Table 1). In addition, strain G13 ${ }^{\mathrm{T}}$ reduced a humic acid analogue, AQDS, fumarate $(20 \mathrm{mM})$ and malate $(20 \mathrm{mM})$. Strain $\mathrm{G} 12^{\mathrm{T}}$ also reduced nitrate $(5 \mathrm{mM})$. Both strains were able to reduce $\mathrm{U}(\mathrm{VI})(1 \mathrm{mM})$ in cell suspension. The following electron acceptors were tested but not utilized by either strain: oxygen ( $5 \%$ of the headspace of the culture), sulfate $(10 \mathrm{mM})$, sulfite $(10 \mathrm{mM})$ and nitrite $(5 \mathrm{mM})$. With PCFO as the electron acceptor, the isolates were capable of oxidizing the following electron donors (at concentrations 10-20 mM): ethanol, butanol, glycerol, acetate, lactate, butyrate, pyruvate and valerate. Strain G13 was also able to use methanol and succinate.

Table 1. Characteristics that differentiate strains $G 12^{\top}$ and $\mathrm{G}_{13}{ }^{\top}$ and related species of the genus Geobacter

Taxa: 1, G. argillaceus sp. nov. $\mathrm{G}^{\mathrm{T}}{ }^{\mathrm{T}} ; 2$, G. pickeringii sp. nov. $\mathrm{G} 13^{\mathrm{T}} ; 3$, G. chapellei $172^{\mathrm{T}}$ (data from Coates et al., 2001); 4, G. hydrogenophilus $\mathrm{H}-2^{\mathrm{T}}$ (Coates et al., 2001); 5, G. metallireducens GS- $15^{\mathrm{T}}$ (Lovley et al., 1993); 6, G. grbiciae TACP-2 ${ }^{\mathrm{T}}$ (Coates et al., 2001). +, Positive; -, negative; ND, not determined.

\begin{tabular}{|c|c|c|c|c|c|c|}
\hline Characteristic & 1 & 2 & 3 & 4 & 5 & 6 \\
\hline DNA G $+\mathrm{C}$ content $(\mathrm{mol} \%)$ & 58.0 & 61.4 & 50.2 & 58.4 & 56.6 & 57.4 \\
\hline Optimal temperature $\left({ }^{\circ} \mathrm{C}\right)$ & 30 & 30 & 25 & 35 & $30-35$ & 30 \\
\hline \multicolumn{7}{|l|}{ Electron acceptors: } \\
\hline AQDS & - & + & ND & $\mathrm{ND}$ & + & + \\
\hline Elemental sulfur & + & + & + & - & - & $\mathrm{ND}$ \\
\hline $\mathrm{Fe}(\mathrm{III}) \mathrm{NTA}$ & + & + & + & - & + & + \\
\hline Ferric citrate & + & + & - & + & + & + \\
\hline Fumarate & - & + & + & + & - & ND \\
\hline Malate & ND & + & - & - & - & $\mathrm{ND}$ \\
\hline $\mathrm{MnOOH}$ & + & + & - & - & + & $\mathrm{ND}$ \\
\hline Nitrate & + & - & - & - & + & $\mathrm{ND}$ \\
\hline \multicolumn{7}{|l|}{ Electron donors: } \\
\hline Butyrate & + & + & - & + & + & + \\
\hline Glycerol & + & + & $\mathrm{ND}$ & $\mathrm{ND}$ & - & $\mathrm{ND}$ \\
\hline $\mathrm{H}_{2}$ & - & - & - & + & - & + \\
\hline Lactate & + & + & + & - & - & - \\
\hline Methanol & - & + & - & - & - & - \\
\hline Succinate & - & + & - & + & ND & - \\
\hline
\end{tabular}


The $\mathrm{G}+\mathrm{C}$ content of the DNA was $58.0 \mathrm{~mol} \%$ for strain $\mathrm{G} 12^{\mathrm{T}}$ and $61.4 \mathrm{~mol} \%$ for strain $\mathrm{G} 13^{\mathrm{T}}$.

\section{Characteristics of strain $\mathbf{R} \mathbf{7}^{\boldsymbol{\top}}$}

Cells of strain $\mathrm{R}^{\mathrm{T}}$ were motile, slightly curved rods, $0.6 \times 2.0-6.0 \mu \mathrm{m}$ (Fig. 2a). Spores were formed in the late exponential phase on all growth substrates. Spores were oval and always in a terminal position (Fig. 2b). The sporangia were distinctly swollen. The presence of up to six flagella was observed by electron microscopy. Flagella were peritrichous and up to $14 \mu \mathrm{m}$ long and $15 \mathrm{~nm}$ wide. Ultrathin sections showed a Gram-negative type of cell wall, with the peptidoglycan layer and outer membrane clearly visible (Fig. 2b).

Optimal growth conditions for this strain were determined using FW medium supplemented with $20 \mathrm{mM}$ glucose.

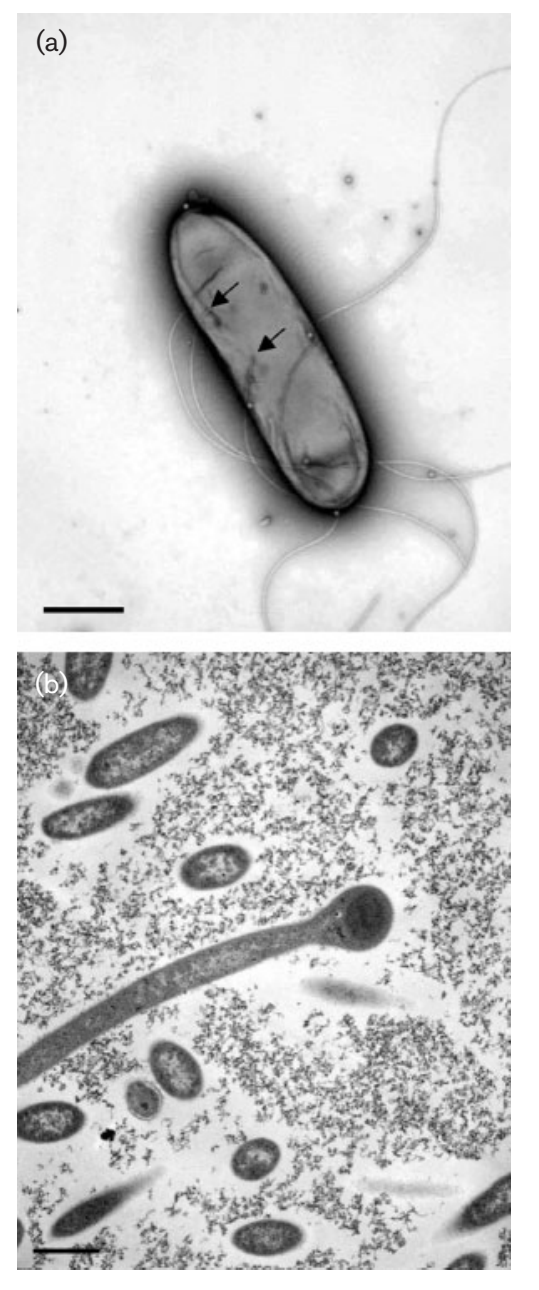

Fig. 2. Morphology of negatively stained (a) and ultrathin section (b) of cells of strain $R 7^{\top}$. Strain $R 7^{\top}$ was grown on glucose. (a) General morphology of a cell showing peritrichous flagella insertion. Arrowheads indicate the flagella insertion points. Bar, $0.5 \mu \mathrm{m}$. (b) Ultrathin section of a cell of strain R7 ${ }^{\top}$ showing cell walls, membranes and spores. Bar, $1 \mu \mathrm{m}$.
Optimal growth was observed at $22-30{ }^{\circ} \mathrm{C}$ and no growth was observed at an initial temperature lower than $4{ }^{\circ} \mathrm{C}$ or higher than $36^{\circ} \mathrm{C}$. The $\mathrm{pH}$ range for growth was between 5.5 and 8 , with an optimum at $\mathrm{pH} 7$.

With hydrogen as the electron donor and acetate as the carbon source, strain $\mathrm{R}^{\mathrm{T}}$ was not capable of utilizing oxygen, AQDS, nitrate, sulfate, sulfite, thiosulfate, Fe(III) NTA, PCFO or elemental sulfur as the electron acceptor. Resting cells of strain $R 7^{\mathrm{T}}$ did not reduce $\mathrm{U}(\mathrm{VI})$ when hydrogen was provided as the electron donor.

Although strain $R 7^{\mathrm{T}}$ was enriched as a $\mathrm{Fe}(\mathrm{III})$ reducer, once isolated, this organism was capable of reducing Fe(III) only in the presence of a fermentable substrate. Strain $R 7^{\mathrm{T}}$ could reduce ferric citrate (FC, Fig. 3a) or Fe(III) pyrophosphate (data not shown), but not Fe(III) NTA (Fig. 3a). The observed growth and reduction of $\mathrm{Fe}$ (III) when FC and $\mathrm{Fe}(\mathrm{III})$ pyrophosphate were provided as the electron acceptors can be explained by the presence of fermentable citrate and organic impurities in these substrates. Acetate was the major product of citrate fermentation by strain $R 7^{\mathrm{T}}$, with an acetate/citrate ratio of $1.9: 1$. This ratio decreased slightly in the presence of FC alone $(1.7: 1)$ or FC and hydrogen (1.4:1) (Fig. 3b). The presence of hydrogen did not increase the $\mathrm{Fe}(\mathrm{III})$ reduction rate (Fig. 3a) or cell yield

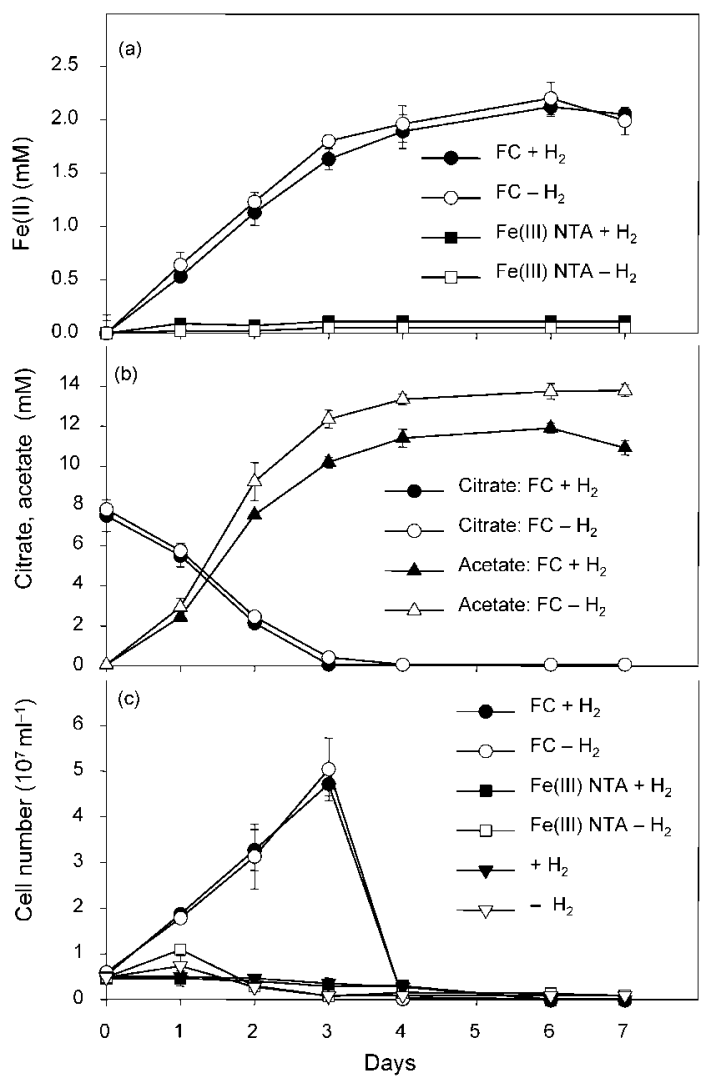

Fig. 3. Fe(III) reduction by strain $R 7^{\top}$. The results are the means of triplicate cultures. FC, ferric citrate. 
(Fig. 3c), suggesting that strain $\mathrm{R} 7^{\mathrm{T}}$ could not use hydrogen as an electron donor. As follows from Fig. $3 c$, strain $\mathrm{R}^{\mathrm{T}}$ was not able to grow chemoautotrophically on $\mathrm{H}_{2} / \mathrm{CO}_{2}$. Strain $\mathrm{R}^{\mathrm{T}}$ reduced $0.3 \mathrm{mM}$ Fe(III) per $1 \mathrm{mM}$ citrate fermented. Together, these data suggest that strain $R 7^{\mathrm{T}}$, as with other fermentative bacteria (Dobbin et al., 1999; Park et al., 2001; Kim et al., 2005; Bhushan et al., 2006), utilizes Fe(III) as an electron sink. Strain $R 7^{\mathrm{T}}$ was also capable of reducing small quantities (1-1.5 mM) AQDS in the presence of fermentable substrates, such as citrate or lactate (data not shown). The use of AQDS as a sink has been demonstrated for several fermentative bacteria, including species of the genera Clostridium (Bhushan et al., 2006) and Cellulomonas (Borch et al., 2005).

Strain $R 7^{\mathrm{T}}$ fermented the following substrates: lactate, butyrate, pyruvate, malate, succinate, citrate, fumarate, fructose, glucose, mannitol, peptone, Casamino acids and yeast extract. The following substrates were tested but not utilized: glycerol, salicylic acid, ascorbate, 2,3-butanediol, maltose, gallic acid, pyrogallol, asparagines, histidine, glycine, leucine, lysine, serine, tyrosine, methionine, phenylalanine, proline, tryptophan, valine, glutamic acid and aspartic acid.
The $\mathrm{G}+\mathrm{C}$ content of the DNA of strain $\mathrm{R} 7^{\mathrm{T}}$ was $41.0 \mathrm{~mol} \%$.

\section{Phylogenetic analyses}

BLAST and similarity analyses of $16 \mathrm{~S}$ rRNA gene sequences indicated that strain $\mathrm{G} 12^{\mathrm{T}}$ was most similar to Geobacter pelophilus (sequence similarity 94.7\%) and Geobacter chapellei $(94.1 \%)$. Strain $\mathrm{G} 13^{\mathrm{T}}$ was most similar to $G$. grbiciae (95.3\%) and Geobacter metallireducens (95.1\%) in the class Deltaproteobacteria. Strain $\mathrm{R}^{\mathrm{T}}$ was most similar to the following micro-organisms of the SporomusaPectinatus-Selenomomas phyletic group: 'Anaerospora hongkongensis' (gene sequence similarity 90.2\%), Acetonema longum (90.6\%), Dendrosporobacter quercicolus (90.9\%) and Anaerosinus glycerini (91.5\%).

Phylogenetic analysis of these and other related sequences was performed using 1200 (Fig. 4a) and 1300 (Fig. 4b) bases for comparison. Placement of strains $G 12^{T}, G 13^{T}$ and $R 7^{T}$ was consistent when using distance and maximumparsimony analyses (Fig. 4a, b). The results indicated that strain $\mathrm{G} 12^{\mathrm{T}}$ was phylogenetically most closely related to $G$. chapellei and strain $\mathrm{G}^{\mathrm{T}} \mathrm{3}^{\mathrm{T}}$ was most closely related to Geobacter hydrogenophilus, G. metallireducens and $G$.
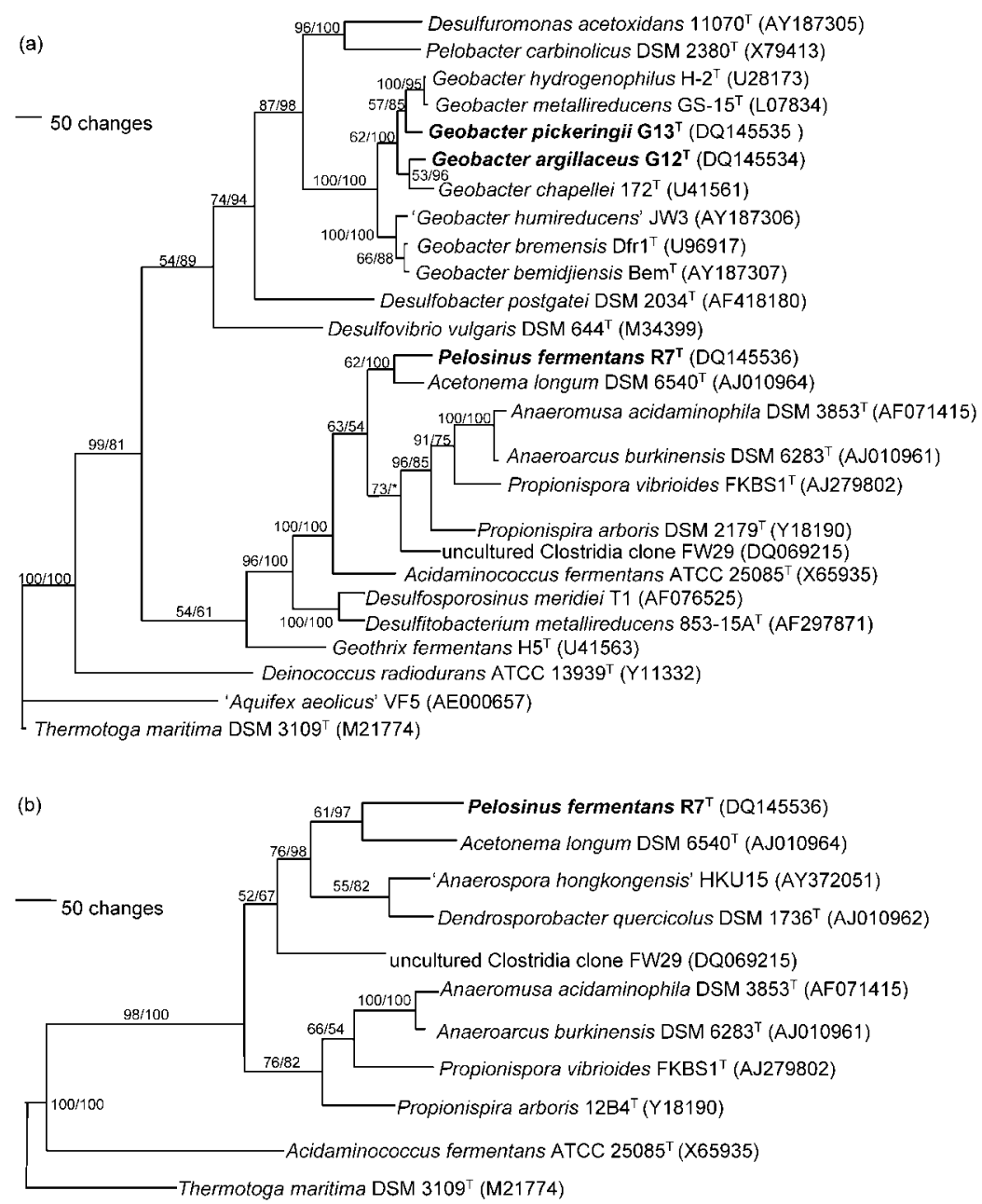

Fig. 4. Phylogenetic analysis of strains $\mathrm{G} 12^{\top}, \mathrm{G} 13^{\mathrm{T}}$ and $\mathrm{R} 7^{\top}$. (a) Phylogenetic tree comparing 16S rRNA gene sequences from the kaolin isolates. Thermotoga maritima and 'Aquifex aeolicus' served as outgroups for the construction of the 16S rRNA gene tree. 1200 positions were considered. (b) Phylogenetic position of strain $\mathrm{R}^{\top}$ within the Sporomusa-Pectinatus-Selenomonas phyletic group. Thermotoga maritima served as an outgroup for the construction of this tree. 1300 positions were considered. Numbers next to branches indicate bootstrap values obtained from 100 replicates by maximum-parsimony/distance-based analysis. Asterisk indicates that distance analysis does not show separate branching for uncultured Clostridia clone FW29. Bars, 50 nucleotide changes. 
grbiciae (Fig. 4a). Based on the phenotypic differences between isolates $\mathrm{G} 12^{\mathrm{T}}$ and $\mathrm{G} 13^{\mathrm{T}}$ and closely related species of the genus Geobacter (Table 1), it is suggested that the isolates represent two novel species, Geobacter argillaceus sp. nov. (strain $\mathrm{G} 12^{\mathrm{T}}$ ) and Geobacter pickeringii sp. nov. (strain $\left.\mathrm{G} 13^{\mathrm{T}}\right)$.

Isolate $\mathrm{R}^{\mathrm{T}}$ grouped with members of the SporomusaPectinatus-Selenomonas phyletic group of the phylum Firmicutes (Strömpl et al., 1999), which is also referred to as clostridial cluster IX (Collins et al., 1994) or the 'Sporomusa branch' (Biebl et al., 2000) (Fig. 4a, b). This phyletic group contains a heterogeneous assemblage of organisms with Gram-negative cell walls, some of which are spore-forming. Strain $\mathrm{R} 7^{\mathrm{T}}$ was phylogenetically most closely related to Acetonema longum (Fig. 4b). Because of the low degree of similarity of the $16 \mathrm{~S}$ rRNA gene sequence of strain $\mathrm{R} 7^{\mathrm{T}}$ with the closest members of the Sporomusa-PectinatusSelenomonas group, as well as significant phenotypic differences (Table 2), we propose to classify this strain as a representative of a new genus and species, Pelosinus fermentans.

\section{Potential role of the novel isolates in iron cycling in kaolin strata}

Of the three organisms described in this paper, two of the isolates are dissimilatory $\mathrm{Fe}$ (III)-reducing bacteria and belong to the genus Geobacter. Like other representatives of this genus (Lovley \& Phillips, 1988; Caccavo et al., 1994; Coates et al., 1996; Straub et al., 1998; Sung et al., 2006), these isolates are capable of obtaining energy for growth by coupling the reduction of $\mathrm{Fe}$ (III) to complete the oxidation of acetate with the ratio of $\mathrm{Fe}$ (II) produced per acetate consumed close to $8: 1$. In contrast, strain $R 7^{\mathrm{T}}$ represents a fermentative organism that is capable of reducing $\mathrm{Fe}$ (III) only in the presence of a fermentable substrate. Strain $R 7^{\mathrm{T}}$ produced only $0.3 \mathrm{mM}$ Fe(II) per $1 \mathrm{mM}$ citrate consumed (Fig. 3). However, despite their lower potential for Fe(III) reduction, fermentative bacteria can be important to the iron geochemistry of kaolin due to the high organic matter content in kaolin $(0.1-5.3 \%$, w/w). The organic matter of kaolins contains various potential electron donors and fermentable substrates for bacterial metabolism such as formate, acetate, lactate, propionate, butyrate, pyruvate,

Table 2. Characteristics that differentiate strain $R 7^{\top}$ and related members of the Sporomusa-Pectinatus-Selenomonas group

Taxa: 1, Pelosinus fermentans sp. nov. R7 ${ }^{\mathrm{T}}$; 2, Acetonema longum APO- ${ }^{\mathrm{T}}$ (data from Kane \& Breznak, 1991); 3, Dendrosporobacter quercicolus DSM $1736^{\mathrm{T}}$ (Stankewich et al., 1971; Strömpl et al., 2000); 4, Anaerosinus glycerini strain LGS $4^{\mathrm{T}}$ (Schauder \& Schink, 1989; Strömpl et al., 1999); 5, 'Anaerospora hongkongensis' HKU15 (Woo et al., 2005). 'Anaerospora hongkongensis' HKU15 was studied using ANI and ATB ID32A test kits (bioMérieux). The physiology of all other strains was examined using a classical cultivation approach. + , Positive; - , negative; ND, not determined.

\begin{tabular}{|c|c|c|c|c|c|}
\hline Characteristic & 1 & 2 & 3 & 4 & 5 \\
\hline $\begin{array}{l}\text { DNA G }+ \text { C } \\
\text { content }(\mathrm{mol} \%)\end{array}$ & 41.0 & 51.5 & $52.0-54.0$ & 35.0 & 46.8 \\
\hline Cell shape & $\begin{array}{l}\text { Slightly curved } \\
\text { rods }\end{array}$ & $\begin{array}{l}\text { Straight } \\
\text { rods }\end{array}$ & $\begin{array}{l}\text { Straight } \\
\text { rods }\end{array}$ & Curved rods & $\begin{array}{l}\text { Straight or slightly } \\
\text { curved rods }\end{array}$ \\
\hline Cell size $(\mu \mathrm{m})$ & $0.6 \times 2-6$ & $0.6 \times 6-60$ & $0.5 \times 3$ & $0.5 \times 2-10$ & $0.4-0.6 \times 3.15-14.30$ \\
\hline Temperature range $\left({ }^{\circ} \mathrm{C}\right)$ & $4-36$ & $19-40$ & $20-45$ & $10-42$ & 37 \\
\hline Temperature optimum $\left({ }^{\circ} \mathrm{C}\right)$ & $22-30$ & $30-33$ & $25-30$ & 37 & ND \\
\hline $\mathrm{pH}$ range & $5.5-8$ & $6.4-8.6$ & ND & $5-8.5$ & ND \\
\hline $\mathrm{pH}$ optimum & 7 & 7.8 & ND & $6.5-7.5$ & ND \\
\hline Flagella & $\begin{array}{c}\text { Up to } 6 \\
\text { peritrichous }\end{array}$ & $\begin{array}{c}1-3 \\
\text { peritrichous }\end{array}$ & $\begin{array}{c}1-3 \\
\text { peritrichous }\end{array}$ & Not found & $\begin{array}{l}\text { Polar flagellae or a tuft of } \\
\text { flagellae inserted on one side }\end{array}$ \\
\hline Spore formation & + & + & + & - & + \\
\hline \multicolumn{6}{|l|}{ Growth on: } \\
\hline Fructose & + & + & + & - & ND \\
\hline Fumarate & + & + & ND & - & $\mathrm{ND}$ \\
\hline Glucose & + & + & $\mathrm{ND}$ & - & - \\
\hline Glycerol & - & - & + & + & - \\
\hline $\mathrm{H}_{2}+\mathrm{CO}_{2}$ & - & + & - & - & $\mathrm{ND}$ \\
\hline Lactate & + & - & ND & - & ND \\
\hline Malate & + & - & ND & - & ND \\
\hline Mannitol & + & + & - & - & - \\
\hline Pyruvate & + & + & ND & - & ND \\
\hline Succinate & + & - & $\mathrm{ND}$ & - & ND \\
\hline
\end{tabular}


oxalate and citrate (Shelobolina et al., 1999, 2005) as well as humic and fulvic acids (Elzea Kogel et al., 2002). At the same time, kaolins are characterized by low amounts of 'bioavailable' $\mathrm{Fe}$ (III) $(0.5 \mathrm{M} \mathrm{HCl}$ extractable hydroxylamine reducable; $0.0-0.9 \mathrm{mmol} \mathrm{kg}{ }^{-1}$ ) compared with total Fe(III) (hydrofluoric acid-extractable, $\quad 7.7-48.6 \mathrm{mmol} \mathrm{kg}{ }^{-1}$ ) (Shelobolina et al., 2005). Electron shuttling via humic acids can explain high levels of microbial $\mathrm{Fe}(\mathrm{III})$ reduction in kaolins in model experiments despite their low 'bioavailable' Fe(III) content (Shelobolina et al., 2005). The important role of fermentative bacteria in humic acidmediated $\mathrm{Fe}$ (III) reduction has been demonstrated for freshwater lake sediments (Kappler et al., 2004). Together, these data suggest that both dissimilatory $\mathrm{Fe}(\mathrm{III})$-reducing and fermentative bacteria could be important contributors to microbial $\mathrm{Fe}(\mathrm{III})$ reduction in kaolin and can be used as model organisms to study biotransformations of iron minerals in kaolin.

\section{Description of Geobacter argillaceus sp. nov.}

Geobacter argillaceus (ar.gil.la'ceus. L. masc. adj. argillaceus of clay).

Cells are Gram-negative, motile, regular rods, $1-2 \mu \mathrm{m}$ long and $0.6 \mu \mathrm{m}$ in diameter. Cells have one lateral flagellum. Optimal growth occurs at $\mathrm{pH} 6.2$ to 6.8 and no growth occurs at initial $\mathrm{pH}$ values lower than 5.8 or higher than 7.4. Growth is most rapid at $30{ }^{\circ} \mathrm{C}$; no growth occurs at temperatures below $10^{\circ} \mathrm{C}$ or above $36^{\circ} \mathrm{C}$. Uses PCFO, ferric citrate, $\mathrm{Fe}(\mathrm{III}) \mathrm{NCA}, \mathrm{Fe}(\mathrm{III})$ pyrophosphate, $\mathrm{MnOOH}$, elemental sulfur and nitrate as electron acceptors. Reduces $\mathrm{U}(\mathrm{VI})$ in cell suspension. Oxidizes the following electron donors: ethanol, butanol, glycerol, acetate, lactate, butyrate, pyruvate and valerate. The $\mathrm{G}+\mathrm{C}$ content of the DNA of the type strain is $58.0 \mathrm{~mol} \%$.

The type strain, $\mathrm{G} 12^{\mathrm{T}}\left(=\right.$ ATCC BAA- $1139^{\mathrm{T}}=\mathrm{JCM} 12999^{\mathrm{T}}$ ), was isolated from subsurface kaolin strata in Georgia, USA.

\section{Description of Geobacter pickeringii sp. nov.}

Geobacter pickeringii (pic.ke.rin'gii. N.L. gen. masc. n. pickeringii of Pickering, named in honour of Sam M. Pickering Jr., for his significant contributions to the study of Georgia kaolins).

Cells are Gram-negative, motile, regular rods, $1-2 \mu \mathrm{m}$ long and $0.6 \mu \mathrm{m}$ in diameter. Cells have one lateral flagellum and exhibit numerous short tubular projections on the cell surface. Optimal growth occurs at $\mathrm{pH} 6.6$ to 7.2; no growth occurs at initial $\mathrm{pH}$ values lower than 5.8 or higher than 8.0. Growth is most rapid at $30{ }^{\circ} \mathrm{C}$; no growth occurs at temperatures below $10^{\circ} \mathrm{C}$ or above $36^{\circ} \mathrm{C}$. Uses PCFO, ferric citrate, Fe(III) NCA, Fe(III) pyrophosphate, $\mathrm{MnOOH}$, elemental sulfur, AQDS, fumarate and malate as electron acceptors. Reduces $U(V I)$ in cell suspension. Oxidizes the following electron donors: methanol, ethanol, butanol, glycerol, acetate, lactate, butyrate, pyruvate, succinate and valerate. The $\mathrm{G}+\mathrm{C}$ content of the DNA of the type strain is $61.4 \mathrm{~mol} \%$.

The type strain, $\mathrm{G}^{3} 3^{\mathrm{T}} \quad\left(=\mathrm{ATCC}\right.$ BAA $-1140^{\mathrm{T}}=\mathrm{DSM}$ $17153^{\mathrm{T}}=\mathrm{JCM} 13000^{\mathrm{T}}$ ), was isolated from sedimentary kaolin strata in Georgia, USA.

\section{Description of Pelosinus gen. nov.}

Pelosinus (Pe.lo.si'nus. Gr. masc. n. pelos mud or clay; L. masc. n. sinus bend; N.L. masc. n. Pelosinus a curved organism from clay).

Cells are Gram-negative, motile, slightly curved rods. Sporeforming. Sporangia are distinctly swollen. Obligately anaerobic. Mesophilic. Does not produce acetate from $\mathrm{H}_{2}+\mathrm{CO}_{2}$. Fermentative. Uses a variety of fermentative substrates, but does not ferment glycerol. The type species is Pelosinus fermentans.

\section{Description of Pelosinus fermentans sp. nov.}

Pelosinus fermentans (fer.men'tans. L. part. adj. fermentans fermenting).

Displays the following features in addition to those given in the genus description. Cells are 2-6 $\mu \mathrm{m}$ long and $0.6 \mu \mathrm{m}$ in diameter. Cells have up to 6 peritrichous flagella. Oval endospores are formed terminally. Optimal growth occurs at $\mathrm{pH}$ 7.0; no growth occurs at initial $\mathrm{pH}$ values lower than 5.5 or higher than 8.0 . Growth is most rapid at $22-30^{\circ} \mathrm{C}$; no growth occurs at temperatures below $4{ }^{\circ} \mathrm{C}$ or above $36^{\circ} \mathrm{C}$. Does not respire anaerobically with $\mathrm{Fe}(\mathrm{III}), \mathrm{AQDS}$, nitrate, sulfate, sulfite, thiosulfate or elemental sulfur, but is capable of using $\mathrm{Fe}(\mathrm{III})$ and AQDS as an electron sink in the presence of fermentable substrate. Does not reduce U(VI) in cell suspension. Ferments the following substrates: lactate, butyrate, pyruvate, malate, succinate, citrate, fumarate, fructose, glucose, mannitol, peptone, Casamino acids and yeast extract. The $\mathrm{G}+\mathrm{C}$ content of DNA of the type strain is $41.0 \mathrm{~mol} \%$.

The type strain, $\mathrm{R}^{\mathrm{T}}\left(=\mathrm{DSM} 17108^{\mathrm{T}}=\mathrm{ATCC}^{\mathrm{BAA}}-1133^{\mathrm{T}}\right)$, was isolated from subsurface primary kaolin deposits in Russia.

\section{ACKNOWLEDGEMENTS}

We would like to thank E. L. Blunt for her technical assistance. We thank S. M. Pickering and J. Elzea Kogel for advice and help with collecting GA kaolins and Thiele Kaolin Co., GA, for access to its mines. We also thank R. A. Khalilullova and Yu. T. Platov for providing us with a sample of kaolin from the Zhuravlinii Log deposit, Plast, Chelabinsk region, Russia. We thank L. Yin at the University of Massachusetts, USA, for helping with the electron micrographs. We are grateful to two anonymous reviewers and to the editor, Professor Peter Kämpfer, for useful comments. This work was supported by NSF NATO (grant DGE-9902554) and by Department of Energy (grant DE-FG02-97ER62475). 


\section{REFERENCES}

Altschul, S. F., Gish, W., Miller, W., Myers, E. W. \& Lipman, D. J. (1990). Basic local alignment search tool. J Mol Biol 215, 403-410.

Avakyan, Z. A., Platov, Y. T., Khaliullova, R. A., Turova, E. S., Karavaiko, G. I., Maslennikova, G. N. \& Vodyanitskii, Y. N. (1997). Method of bleaching of argillaceous ceramic materials. Russian Federation Patent no. 2083527.

Balch, W. E., Fox, G. E., Magrum, L. J., Woese, C. R. \& Wolfe, R. S. (1979). Methanogens: reevaluation of a unique biological group. Microbiol Rev 43, 260-296.

Beveridge, T. J. (1999). Structures of Gram-negative cell walls and their derived membrane vesicles. J Bacteriol 181, 4725-4733.

Bhushan, B., Halasz, A. \& Hawari, J. (2006). Effect of iron(III), humic acids and anthraquinone-2,6-disulfonate on biodegradation of cyclic nitramines by Clostridium sp. EDB2. J Appl Microbiol 100, 555-563.

Biebl, H., Schwab-Hanisch, H., Sproer, C. \& Lunsdorf, H. (2000). Propionispora vibrioides, nov. gen., nov. sp., a new Gram-negative, spore-forming anaerobe that ferments sugar alcohols. Arch Microbiol 174, 239-247.

Borch, T., Inskeep, W. P., Harwood, J. A. \& Gerlach, R. (2005). Impact of ferrihydrite and anthraquinone-2,6-disulfonate on the reductive transformation of 2,4,6-trinitrotoluene by a Gram-positive fermenting bacterium. Environ Sci Technol 39, 7126-7133.

Caccavo, F., Lonergan, D. J., Lovley, D. R., Davis, M., Stolz, J. F. \& McInerney, M. J. (1994). Geobacter sulfurreducens sp. nov., a hydrogen- and acetate-oxidizing dissimilatory metal-reducing microorganism. Appl Environ Microbiol 60, 3752-3759.

Cashion, P., Holder-Franklin, M.A., McCully, J. \& Franklin, M. (1977). A rapid method for the base ratio determination of bacterial DNA. Anal Biochem 81, 461-466.

Ciofu, O., Beveridge, T. J., Kadurugamuwa, J. L., Walther-Rasmussen, J. \& Hoiby, N. (2000). Chromosomal $\beta$-lactamase is packaged into membrane vesicles and secreted from Pseudomonas aeruginosa. J Antimicrob Chemother 45, 9-13.

Cline, J. D. (1969). Spectrophotometric determination of hydrogen sulfide in natural waters. Limnol Oceanogr 14, 454-458.

Coates, J. D., Phillips, E. J., Lonergan, D. J., Jenter, H. \& Lovley, D. R. (1996). Isolation of Geobacter species from diverse sedimentary environments. Appl Environ Microbiol 62, 1531-1536.

Coates, J. D., Bhupathiraju, V. K., Achenbach, L. A., Mclnerney, M. J. \& Lovley, D. R. (2001). Geobacter hydrogenophilus, Geobacter chapellei and Geobacter grbiciae, three new, strictly anaerobic, dissimilatory Fe(III)-reducers. Int J Syst Evol Microbiol 51, 581-588.

Collins, M. D., Lawson, P. A., Willems, A., Cordoba, J. J., Fernandez-Garayzabal, J., Garcia, P., Cai, J., Hippe, H. \& Farrow, J. A. E. (1994). The phylogeny of the genus Clostridium: proposal of five new genera and eleven new species combinations. Int $J$ Syst Bacteriol 44, 812-826.

Dobbin, P. S., Carter, J. P., San Juan, C. G.-S., von Hobe, M., Powell, A. K. \& Richardson, D. J. (1999). Dissimilatory Fe(III) reduction by Clostridium beijerinckii isolated from freshwater sediment using $\mathrm{Fe}$ (III) maltol enrichment. FEMS Microbiol Lett 176, 131-138.

Dorward, D. W., Garon, C. F. \& Judd, R. C. (1989). Export and intercellular transfer of DNA via membrane blebs of Neisseria gonorrhoeae. J Bacteriol 171, 2499-2505.

Dorward, D. W. \& Garon, C. F. (1990). DNA is packaged within membrane-derived vesicles of Gram-negative but not Gram-positive bacteria. Appl Environ Microbiol 56, 1960-1962.

Elzea Kogel, J., Pickering, S. M., Jr, Shelobolina, E. S., Chowns, T. M., Yuan, J. \& Avant, D. M., Jr (2002). The Georgia Kaolins: Geology and Utilization. Littleton, CO, USA: Society for Mining, Metallurgy, and Exploration.

Forsberg, C. W., Beveridge, T. J. \& Hellstrom, A. (1981). Cellulase and xylanase release from Bacteroides succinogenes and its importance in the rumen environment. Appl Environ Microbiol 42, 886-896.

Gonzalez, J. M. \& Saiz-Jimenez, C. (2002). A fluorimetric method for the estimation of $\mathrm{G}+\mathrm{C}$ mol\% content in microorganisms by thermal denaturation temperature. Environ Microbiol 4, 770-773.

Gonzalez, J. M. \& Saiz-Jimenez, C. (2004). Using the iCycler $i Q^{\circledR}$ Detection System to Estimate Microbial DNA base composition from Melting Curves. Hercules, CA, USA: Bio-Rad Laboratories, Inc.

Grenier, D. \& Mayrand, D. (1987). Functional characterization of extracellular vesicles produced by Bacteroides gingivalis. Infect Immun 55, 111-117.

Hobbie, J. E., Daley, R. J. \& Jasper, S. (1977). Use of nuclepore filters for counting bacteria by fluorescence microscopy. Appl Environ Microbiol 33, 1225-1228.

Hungate, R. E. (1969). A roll tube method for cultivation of strict anaerobes. Methods Microbiol 3B, 117-132.

Hurst, V. J. \& Pickering, S. M. Jr (1997). Origin and classification of Coastal Plain kaolins, southeastern USA, and the role of groundwater and microbial action. Clays Clay Miner 45, 274-285.

Kadurugamuwa, J. L. \& Beveridge, T. J. (1996). Bacteriolytic effect of membrane vesicles from Pseudomonas aeruginosa on other bacteria including pathogens: conceptually new antibiotics. J Bacteriol 178, 2767-2774.

Kadurugamuwa, J. L., Mayer, A., Messner, P., Sara, M., Sleytr, U. B. \& Beveridge, T. J. (1998). S-layered Aneurinibacillus and Bacillus spp. are susceptible to the lytic action of Pseudomonas aeruginosa membrane vesicles. I Bacteriol 180, 2306-2311.

Kane, M. D. \& Breznak, J. A. (1991). Acetonema longum gen. nov. sp. nov., an $\mathrm{H}_{2} / \mathrm{CO}_{2}$ acetogenic bacterium from the termite, Pterotermes occidentis. Arch Microbiol 156, 91-98.

Kappler, A., Benz, M., Schink, B. \& Brune, A. (2004). Electron shuttling via humic acids in microbial iron(III) reduction in a freshwater sediment. FEMS Microbiol Ecol 47, 85-92.

Kashefi, K. \& Lovley, D. R. (2000). Reduction of Fe(III), Mn(IV), and toxic metals at $100{ }^{\circ} \mathrm{C}$ by Pyrobaculum islandicum. Appl Environ Microbiol 66, 1050-1056.

Kim, G. T., Hyun, M. S., Chang, I. S., Kim, H. J., Park, H. S., Kim, B. H., Kim, S. D., Wimpenny, J. W. T. \& Weightman, A. J. (2005). Dissimilatory $\mathrm{Fe}(\mathrm{III})$ reduction by an electrochemically active lactic acid bacterium phylogenetically related to Enterococcus gallinarum isolated from submerged soil. J Appl Microbiol 99, 978-987.

Kobayashi, H., Uematsu, K., Hirayama, H. \& Horikoshi, K. (2000). Novel toluene elimination system in a toluene-tolerant microorganism. J Bacteriol 182, 6451-6455.

Komadel, P. \& Stucki, J. W. (1988). Quantitative assay of minerals for $\mathrm{Fe}^{2+}$ and $\mathrm{Fe}^{3+}$ using 1,10-phenanthroline; III, A rapid photochemical method. Clays Clay Miner 36, 379-381.

Kuehn, M. J. \& Kesty, N. C. (2005). Bacterial outer membrane vesicles and the host-pathogen interaction. Genes Dev 19, 2645-2655. Küsel, K., Dorsch, T., Acker, G. \& Stackebrandt, E. (1999). Microbial reduction of $\mathrm{Fe}(\mathrm{III})$ in acidic sediments: isolation of Acidiphilium cryptum JF-5 capable of coupling the reduction of $\mathrm{Fe}(\mathrm{III})$ to the oxidation of glucose. Appl Environ Microbiol 65, 3633-3640.

Lee, E.-Y., Cho, K.-S., Ryu, H. W. \& Chang, Y. K. (1999). Microbial removal of $\mathrm{Fe}(\mathrm{III})$ impurities from clay using dissimilatory iron reducers. J Biosci Bioeng 87, 397-399. 
Li, Z., Clarke, A. J. \& Beveridge, T. J. (1998). Gram-negative bacteria produce membrane vesicles which are capable of killing other bacteria. J Bacteriol 180, 5478-5483.

Lovley, D. R. \& Phillips, E. J. (1986a). Organic matter mineralization with reduction of ferric iron in anaerobic sediments. Appl Environ Microbiol 51, 683-689.

Lovley, D. R. \& Phillips, E. J. P. (1986b). Availability of ferric iron for microbial reduction in bottom sediments of the freshwater tidal Potomac River. Appl Environ Microbiol 52, 751-757.

Lovley, D. R. \& Phillips, E. J. P. (1988). Novel mode of microbial energy metabolism: organic carbon oxidation coupled to dissimilatory reduction of iron or manganese. Appl Environ Microbiol 54, 1472-1480.

Lovley, D. R., Stolz, J. F., Nord, G. L. \& Phillips, E. J. P. (1987) Anaerobic production of magnetite by a dissimilatory iron-reducing microorganism. Nature 330, 252-254.

Lovley, D. R., Giovannoni, S. J., White, D. C., Champine, J. E., Phillips, E. J. P., Gorby, Y. A. \& Goodwin, S. (1993). Geobacter metallireducens gen. nov. sp. nov., a microorganism capable of coupling the complete oxidation of organic compounds to the reduction of iron and other metals. Arch Microbiol 159, 336-344.

Lovley, D. R., Holmes, D. E. \& Nevin, K. P. (2004). Dissimilatory $\mathrm{Fe}(\mathrm{III})$ and $\mathrm{Mn}(\mathrm{IV})$ reduction. Adv Microb Physiol 49, 219-286.

Manceau, A., Lanson, B., Drits, V. A., Chateigner, D., Gates, W. P., Wu, J., Huo, D. \& Stucki, J. W. (2000). Oxidation-reduction mechanism of iron in dioctahedral smectites: I. Crystal chemistry of oxidized reference nontronites. Am Mineral 85, 133-152.

Miller, T. L. \& Wolin, M. J. (1974). A serum bottle modification of the Hungate technique for cultivating obligate anaerobes. Appl Microbiol 27, 985-987.

Osipov, G. A. \& Turova, E. S. (1997). Studying species composition of microbial communities with the use of gas chromatography-mass spectrometry: microbial community of kaolin. FEMS Microbiol Rev 20, 437-446.

Park, H. S., Kim, B. H., Kim, H. S., Kim, H. J., Kim, G. T., Kim, M., Chang, I. S., Park, Y. K. \& Chang, H. I. (2001). A novel electrochemically active and $\mathrm{Fe}(\mathrm{III})$ reducing bacterium phylogenetically related to Clostridium butyricum isolated from a microbial fuel cell. Anaerobe 7, 297-306.

Phillips, E. J. P. \& Lovley, D. R. (1987). Determination of Fe(III) and $\mathrm{Fe}(\mathrm{II})$ in oxalate extracts of sediment. Soil Sci Soc Am J 51, 938-941.

Schauder, R. \& Schink, B. (1989). Anaerovibrio glycerini sp. nov., an anaerobic bacterium fermenting glycerol to propionate, cell matter, and hydrogen. Arch Microbiol 152, 473-478.

Shelobolina, E. S., Parfenova, E. Y. \& Avakyan, Z. A. (1999). Microorganisms of kaolins and their role in the processes of iron solubilization and transformation. In Biohydrometallurgy and the Environment Toward the Mining of the 21st Century, part A, pp. 559-568. Edited by A. Amils \& A. Ballester. Amsterdam: Elsevier.

Shelobolina, E. S., Gaw VanPraagh, C. \& Lovley, D. R. (2003). Use of ferric and ferrous iron containing minerals for respiration by Desulfitobacterium frappieri. Geomicrobiology J 20, 143-156.

Shelobolina, E. S., Sullivan, S., O'Neill, K. R., Nevin, K. P. \& Lovley, D. R. (2004). Isolation, characterization, and U(VI)-reducing potential of a facultatively anaerobic, acid-resistant bacterium from low-pH, nitrate- and U(VI)-contaminated subsurface sediment and description of Salmonella subterranea sp. nov. Appl Environ Microbiol 70, 2959-2965.
Shelobolina, E. S., Pickering, S. M. Jr \& Lovley, D. R. (2005). Fecycle bacteria from industrial clays mined in Georgia, USA. Clays Clay Miner 53, 580-586.

Solodkii, N. F. (1995). Eluvial Kaolin from the Zhuravlinyi Log Deposit as a New Source of High-Quality Material for Fine Ceramics Production. An Analytical Review. Moscow: VNIIESM.

Stankewich, J. P., Cosenza, B. J. \& Shigo, A. L. (1971). Clostridium quercicolum, sp. nov., isolated from discolored tissues in living oak trees. Antonie van Leeuwenhoek 37, 299-302.

Straub, K., Hanzlik, M. \& Buchholz-Cleven, B. E. (1998). The use of biologically produced ferrihydrite for the isolation of novel ironreducing bacteria. Syst Appl Microbiol 21, 442-449.

Strömpl, C., Tindall, B. J., Jarvis, G. N., Lünsdorf, H., Moore, E. R. B. \& Hippe, H. (1999). A re-evaluation of the taxonomy of the genus Anaerovibrio, with the reclassification of Anaerovibrio glycerini as Anaerosinus glycerini gen. nov., comb. nov., and Anaerovibrio burkinabensis as Anaeroarcus burkinensis [corrig.] gen. nov., comb. nov. Int J Syst Bacteriol 49, 1861-1872.

Strömpl, C., Tindall, B. J., Lünsdorf, H., Wong, T.-Y., Moore, E. R. \& Hippe, H. (2000). Reclassification of Clostridium quercicolum as Dendrosporobacter quercicolus gen. nov., comb. nov. Int J Syst Evol Microbiol 50, 101-106.

Stucki, J. W. (1981). The quantitative assay of minerals for $\mathrm{Fe}^{2+}$ and $\mathrm{Fe}^{3+}$ using 1,10-phenanthroline: II. A photochemical method. Soil Sci Soc Am J 45, 638-641.

Sung, Y., Fletcher, K. E., Ritalahiti, K. M., Apkarian, R. P., Ramos-Hernandez, N., Sanford, R. A., Mesbah, N. M. \& Loffler, F. E. (2006). Geobacter lovleyi sp nov strain SZ, a novel metalreducing and tetrachloroethene-dechlorinating bacterium. Appl Environ Microbiol 72, 2775-2782.

Swofford, D. (1998). PAUP*: Phylogenetic analysis using parsimony (*and other methods), version 4. Sunderland, MA: Sinauer Associates.

Turova, E. S., Avakyan, Z. A. \& Karavaiko, G. I. (1996). The role of a bacterial community in transformation of iron minerals in kaolin. Microbiology (English translation of Mikrobiologiya) 65, 837-843.

Vodyanitskii, Y. N., Turova, E. S., Avakyan, Z. A. \& Karavaiko, G. I. (1997). Studying anaerobiosis in a model experiment with kaolin. Eurasian Soil Sci 30, 747-757.

Wensink, J. \& Witholt, B. (1981). Outer-membrane vesicles released by normally growing Escherichia coli contain very little lipoprotein. Eur J Biochem 116, 331-335.

Whitchurch, C. B., Tolker-Nielsen, T., Ragas, P. C. \& Mattick, J. S. (2002). Extracellular DNA required for bacterial biofilm formation. Science 295, 1487.

Woo, P. C. Y., Teng, J. L. L., Leung, K. W., Lau, S. K. P., Woo, G. K. S., Wong, A. C. Y., Wong, M. K. M. \& Yuen, K. Y. (2005). Anaerospora hongkongensis gen. nov. sp. nov., a novel genus and species with ribosomal DNA operon heterogeneity isolated from an intravenous drug abuser with pseudobacteremia. Microbiol Immunol 49, 31-39.

Yaron, S., Kolling, G. L., Simon, L. \& Matthews, K. R. (2000). Vesiclemediated transfer of virulence genes from Escherichia coli O157:H7 to other enteric bacteria. Appl Environ Microbiol 66, 4414-4420.

Zhou, L., Srisatjaluk, R., Justus, D. E. \& Doyle, R. J. (1998). On the origin of membrane vesicles in Gram-negative bacteria. FEMS Microbiol Lett 163, 223-228. 